\title{
MEMULAI PENELITIAN DENGAN MENGANALISIS TOPIK KEILMUAN
}

\author{
Ismail Suardi Wekke \\ Sekolah Tinggi Agama Islam Negeri (STAIN) Sorong \\ Research Associate Universiti Sains Malaysia, Malaysia \\ Email: ismail@stain-sorong.ac.id.
}

\begin{abstract}
Research is one of the key to extend knowledge development. Therefore, the first step to identify the discourse starts to understand the position of the issue. During literature understanding, researcher will identify the topic position on the discourse. This step avoids us from redundancy and replication. This paper also discusses the first step research identification to religious communication.
\end{abstract}

Keywords: penelitian, topik, intedisipliner

\section{PENDAHULUAN}

Ada sifat manusiawi yang setiap individu memilikinya yaitu rasa ingin tahu. Ini tumbuh secara alami, ketika seorang anak mulai dapat bercakap, maka dimulai bertanya “apa ini?" dan "apa itu?". Proses ini kemudian menjadi tanda adanya keinginan setiap orang untuk mempertanyakan sebuah hal. Sekaligus ini juga sebagai awal dalam tahapan penelitian. Keinginantahuan itu kemudian menjadi sebuah pertanyaan yang perlu dijawab. Perbedaan utama antara penelitian dengan observasi atau survei pemilihan umum terletak pada pola ilmiah. Walaupun juga dalam sebuah survei menggunakan pola ilmiah tetapi tidak sepenuhnya karena keinginantahuan akademik, tetapi karena kepentingan politik. Adapun penelitian dalam pengertian sebenarnya mengandung sebuah konsekwensi untuk senantiasa mengikuti fatsoen dari bentuk yang sudah menjadi konvensi.

Dalam hal tertentu, sama halnya ketika seseorang tertarik membeli barang. Sebelum memutuskan membeli barang yang diinginkan, maka dilakukan "penelitian" tentang kualitas, harga, dan selera pembeli. Tetapi itu semata-mata tergantung kepada kebutuhan, keadaan, dan kondisi masing-masing pembeli. Tidak ada langkah baku dalam proses "penelitian" sebelum membeli barang. Semata-mata kondisional, dalam setiap kasus individual. Tidak memerlukan acuan baku yang menjadi kesepakatan konsumen.

Berbeda dengan sebuah soal, ketika seorang individu mengajukan sebuah pertanyaan, dapat saja mendapatkan jawaban dari orang lain. Namun, ada pula pertanyaan yang perlu mendapatkan keyakinan dari lapangan karena jawaban yang didapatkan belum 
dapat menjelaskan keseluruhan soal yang diajukan. Dari sini, dapat saja seseorang melakukan usaha mencari jawaban atau mungkin juga dibarengi dengan pembuktian.

Penelitian menjadi proses yang berlangsung terus menerus untuk memupuk bangunan keilmuan. Temuah penelitian yang sudah didapatkan peneliti sebelumnya dapat saja dibantah dan diperbarui dengan sebuah teori baru. Bisa saja sebuah penelitian yang ada, tidak tepat dalam melakukan analisis sehingga kesimpulan yang berbeda dengan apa yang seharusnya digambarkan. Kadang kala juga penelitian sebelumnya menjadi dasar bagi penelitian selanjutnya. Dari sini tergambar bahwa pola ilmiah memandu perkembangan ilmu dan mendorong kepada kelanjutan akan proses keilmuan.

Sebuah penelitian jika sudah diawali dengan pertanyaan, selanjutnya ada langkahlangkah yang terstruktur untuk mendapatkan jawaban dari pertanyaan tersebut. Kelaziman langkah dan tahapan yang akan dilakukan menjadi sebuah karakter penelitian itu sendiri. Dari langkah yang ilmiah dan proses yang dipastikan juga ilmiah, maka apapun hasilnya akan disebut juga ilmiah. Ini karena dua faktor tadi, langkah dan proses yang dilakukan.

Organisasi penelitian secara sistematis dan logis menjadi dua tanda utama sebuah penelitian. Dengan mengacu kepada standar baku, maka terdapat lima langkah dalam siklus sebuah penelitian yaitu (1) merumuskan masalah penelitian, (2) kajian empiris sesuai data yang menjadi target, (3) pengulangan dan pengecekan keabsahan data, (4) analisis, sintesis, dan mengkaji hubungan antar bagian, dan (5) mengolah dan mengevaluasi. Kelima tahap ini tetap juga harus mengacu kepada prinsip dan kaidah yang lazim.

Walaupun awalnya bersifat spekulatif, tetapi pada prosedur selanjutnya tidak dapat dilakukan secara spekulatif. Perlu menghindari sifat sempit dan mekanis semata. Justru harus dilakukan penjelasan dan alasan yang kuat guna meyakinkan masyarakat akademik dalam memahami kajian yang dilakukan. Cara, sistematika, argumen, dan nalar, kesemuanya ditujukan untuk menghasilkan sebuah kesimpulan yang berdasar pada fakta.

Sehingga sifat faktual menjadi ciri utama yang lain dalam proses ilmiah. Ini untuk memenuhi objektifitas hasil yang diperoleh. Dengan mengacu kepada objektifitas itu, maka semua hasil yang didapatkan sudah menghindari unsur-unsur subyektif peneliti. Ini juga dijaga dengan adanya sebuah konsistensi baik dalam proses maupun hasil.

Pemahaman akan pola dan sikap ilmiah perlu diketahui sejak awal sehingga dalam proses menjalankan sebuah penelitian senantiasa berpegang teguh kepada prinsip-prinsip ini. Prinsip penelitian akan membantu seorang peneliti dalam memahami konstruksi obyek 
kajian, sekaligus memberikan sebuah sudut pandang. Dengan demikian, akan dapat dijelaskan sebuah fenomena berdasarkan pertanyaan yang diajukan. Ini menunjukkan perlunya keteguhan dalam mengaplikasikan tata cara akademik untuk memenuhi semua keinginantahuan dalam bingkai yang ilmiah. Masyarakat akademik sudah membakukan prinsip-prinsip dan kaedah yang harus ditempuh dalam rangkaian pencarian kebenaran ilmiah itu.

\section{APLIKASI PENELITIAN DAKWAH}

Sebuah penelitian tidak harus mengemukakan kajian dengan fokus pada disiplin tertentu saja. Sebagaimana dakwah tidak hanya bisa didekati dengan perspektif teologi. Atau bahkan hanya sampai pada dakwah an sich semata. Topik dakwah dapat dikaji secara luas. Begitu pula dapat menggabungkan dua hal dalam satu kajian. Dimana ruang-ruang kehidupan tidak bisa berdiri sendiri tanpa keterlibatan aspek lain. Sehingga dengan mengidentifikasi apsek dakwah dengan menggandeng pokok bahasan dari bidang lain sangat memungkinkan, bahkan dianjurkan.

Sebagai contoh, lembaga pendidikan Islam tidak dapat melepaskan diri dari fungsifungsi dakwah (Wekke, 2013). Maka, unsur pendidikan, dakwah, dan lingkungan madrasah menjadi tiga variable yang dikaji untuk mendapatkan sebuah penjelasan fenomena. Kata kunci dari awal sebuah penelitian adalah faktual, bukan mengada-ada. Contoh berikutnya adalah lembaga pendidikan dalam kaitan dengan pembelajaran kewirausahaan. Pendidikan Islam mengemban tugas sebagai wadah pembelajaran (tafaquh fi al-din). Dalam perkembangannya, tidak hanya soal pendidikan semata yang diselesaikan. Sebuah lembaga pendidikan seperti Roudhatul Khuffadz tidak saja melatih para santri untuk sekadar menguasai pemahaman keagamaan, melainkan juga membekali santri dengan kemahiran untuk hidup di masyarakat pada saatnya. Maka, kemampuan untuk berwirausaha dijadikan sebagai salah satu program latihan para santri (Wekke, 2017; Wekke, 2011).

Dakwah tidak berkaitan dengan mimbar saja. Seluruh aspek kemanusiaan bisa saja dilihat dalam perspektif dakwah. Dengan catatan penting, tidak mengada-ada. Sebuah praktik penggunaan tifa syawat bisa saja dikaji dalam kaitan dengan aspek dakwah. Maka, walaupun itu hanya sebuah kesenian semata tetapi tidak data dilihat hanya sebagais ebuah kesenian saja (Wekke, \& Sari, 2014). Begitu pula dengan perguruan tinggi, dimana keberadaan perguruan tinggi mengemban fungsi tri dharma pendidikan. Hanya saja, sebuah 
perguruan tinggi dapat dicermati dalam aspek dakwah. Tetapi tidak dalam batasan peran, ataupun melihat secara satu arah saja. Pendidikan tinggi dapat dicermati dengan memperhatikan aspek keberagaman mahasiswa (Wekke, Hermawanto, \& Ashrori, 2017). Bagian yang bisa dicermati juga adalah kaitan antara keberagamaan dengan adat (Wekke, 2014). Dimana Islam yang berkembang tidak dapat dilepaskan dari perjumpaan dengan adat yang sudah mentradisi.

Studi kasus berikutnya, pembelajaran agama Islam. Pendidikan Islam berhubungkait dengan pelbagai dinamika kehidupan. Maka, mengkaji sebuah lembaga pendidikan tidak saja berkait dengan manajemen (Wekke, Rubawati, \& Nurjannah, 2017), kurikulum (Wekke, \& Astuti, 2017; Wekke, 2016). Tetapi juga ada aspek toleransi (Mokodenseho, \& Wekke, 2017). Begitupula dengan menelusuri dua aspek dalam sebuah pembelajaran (Wekke, Umbar, \& Arsyad, 2016). Termasuk, ada aspek tradisi dalam aktivitas kependidikan (Wekke, 2015), dan kelembagaan (Wekke, Siddin, \& Kasop, 2017).

Uraian tersebut menjadi gambaran bahwa untuk menemukan sebuah topik perlu melakukan observasi. Melengkapi bacaan dengan tambahan pengamatan akan menjadikan topik yang dikaji sudah memiliki landasan awal, sehingga keputusan untuk meneliti dapat dilanjutkan ke tahap selanjutnya. Pengamatan mendalam menjadi kunci untuk mengidentifikasi sebuah fenomena.

Langkah selanjutnya adalah memahami konteks fenomena tersebut dalam diskursus keilmuan. Tidak ada penelitian yang sama sekali baru. Hanya saja, menggunakan analisis tertentu, perspektif baru, ataupun dengan tambahan variable baru, akan menjadis ebuah kesempatan untuk melakukan studi kembali. Ini mengacu kepada hakikat penelitian yang dimulai dengan kesempatan kembali (re). Penelitian akan memberi kesempatan untuk mencari sebuah pertanyaan dengan jawaban dari realitas.

\section{PENUTUP}

Penelitian perlu diidentifikasi dengan memulai menelisik topik-topik yang sudah terpublikasi. Sehingga jawaban atas fenomena yang belum diketahui tidak serta-merta merupakan sesuatu yang "gelap". Justru dengan menelisik kepustakaan akan membantu memahami diskursus sebuah topik dalam konteks yang lebih besar. Untuk itu, pembacaan terhadap topik yang sama perlu dilakukan. Begitu juga dengan mengkaji topik dalam bentuk interdisipliner. Menempatkan sebuah aspek yang bersisian dengan topik utama akan memperlihatkan bentuk kajian yang komprehensif. 
Berikutnya, tidak ada sama sekali sesuatu di muka bumi ini benda yang baru. Untuk itu, dengan menelusuri literatur yang ada akan membantu kita menempatkan posisi sebuah topik dalam wacana. Sehingga akan menghindarkan kita dari replikasi ataupun pengulangan topik.

\section{DAFTAR PUSTAKA}

Mokodenseho, S., \& Wekke, I. S. (2017). Toleransi Beragama dan Pembelajaran Agama Islam. PROSIDING, 1(1), 67-75.

Wekke, I. S. (2011). Pendidikan Islam dan Pemberdayaan Masyarakat (Tinjauan Pendidikan Vokational Pesantren Raudhatul Khuffadz, Sorong). Jurnal Kajian Islam Interdisipliner Hermenia, 10(1): 23-53.

Wekke, I. S. (2013). Lembaga Pendidikan Sebagai Pilar Dakwah di Wilayah Minoritas Muslim. Jurnal Dakwah Alhikmah, 4(2), 93-118.

Wekke, I. S. (2014). Islam dan Adat dalam Pernikahan Masyarakat Bugis di Papua Barat. THAQAFIYYAT: Jurnal Bahasa, Peradaban dan Informasi Islam, 13(2).

Wekke, I. S. (2015). Tradisi Pesantren Dalam Konstruksi Kurikulum Bahasa Arab di Lembaga Pendidikan Minoritas Muslim Papua Barat. KARSA: Journal of Social and Islamic Culture, 22(1), 20-38.

Wekke, I. S. (2016). Curriculum Development in Madrasa: Exploration from Muslim Minority of West Papua. Jurnal Pendidikan Islam, 1(3), 372-392.

Wekke, I. S. (2017). Integrasi Pendidikan Islam dan Pembelajaran Kewirausahaan di Pesantren Minoritas Muslim. Fenomena, 9(1), 1-24.

Wekke, I. S., \& Astuti, R. W. (2017). Kurikulum 2013 di Madrasah Ibtidaiyah: Implementasi di Wilayah Minoritas Muslim. Tadris: Jurnal Keguruan dan Ilmu Tarbiyah, 2(1), 33-39.

Wekke, I. S., \& Sari, Y. R. (2014). Tifa Syawat dan Entitas Dakwah dalam Budaya Islam: Studi Suku Kokoda Sorong Papua Barat. THAQAFIYYAT: Jurnal Bahasa, Peradaban dan Informasi Islam, 13(1), 163-186.

Wekke, I. S., Hermawanto, A., \& Ashrori, M. (2017). Keberagamaan Mahasiswa Di Perguruan Tinggi Wilayah Minoritas Muslim. ULUL ALBAB Jurnal Studi Islam, 17(2), 135-146.

Wekke, I. S., Rubawati, E., \& Nurjannah, S. (2017). Kepemimpinan Transformatif Di Madrasah Minoritas Muslim Papua Barat. J-MPI (Jurnal Manajemen Pendidikan Islam), 2(1).

Wekke, I. S., Siddin, S., \& Kasop, I. (2017). Pesantren, Madrasah, Sekolah, dan Panti Asuhan. At-Tajdid: Jurnal Ilmu Tarbiyah, 6(1).

Wekke, I. S., Umbar, K., \& Arsyad, A. (2016). Tradisionalisme dan Modernisme Pembelajaran Bahasa Arab: Pembelajaran Madrasah Berbasis Pesantren Minoritas Muslim. Prosiding Konfererensi Nasional Bahasa Arab, 1(2). 